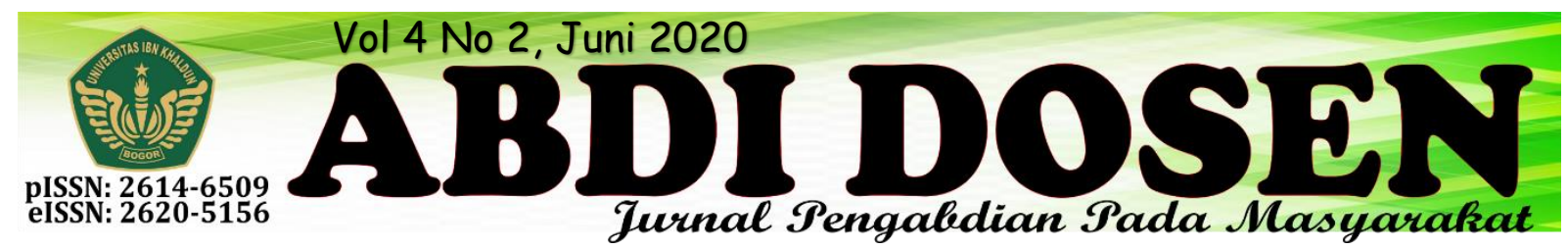

\title{
PENINGKATAN FUNGSISONAL ELEMEN MASYARAKAT DALAM BIDANG PENDIDIKAN, KESEHATAN, PEREKONOMIAN DAN HUKUM MELALUI TEKHNOLOGI YANG MEMBANGUN KESEJAHTERAAN MASYARAKAT
}

\author{
Roy Waluyo ${ }^{1}$, Abrista Devi $^{2}$, Amelia $^{3}$ \\ roy.waluyo@uika-bogor.ac.id ${ }^{1}$ \\ abristadevi@fai.uika-bogor.ac.id ${ }^{2}$ \\ Fakultas Teknik Universitas Ibn Khaldun ${ }^{1}$, Fakultas Agama Islam Universitas Ibn Khaldun², Mahasiswa KKN \\ Kelompok $17 \& 182019^{3}$
}

\begin{abstract}
ABSTRAK
Kuliah Kerja Nyata Tematik Terintegrasi 2019 merupakan salah satu program pengabdian mahasiswa pada masyarakat yang diselenggarakan oleh Universitas Ibn Khaldun Bogor. Kegiatan KKN ini dilaksanakan khususnya pada Masyarakat RT 02/RW $02 \mathrm{kp}$. Neglasari Desa Karyasari, Kecamatan Leuwiliang, Kabupaten Bogor dengan program "Peningkatan Fungsional Elemen Masyarakat Dalam Bidang Pendidikan, Kesehatan, Perekonomian Dan Hukum Melalui Tekhnologi Yang Membangun Kesejahteraan Masyarakat Desa Karyasari" dengan pelaksanaan kegiatannya dalam bentuk pengabdian pada masyarakat terhitung mulai tanggal 06 Agustus 2019 sampai 06 September 2019. Metode yang digunakan dalam kegiatan KKN adalah berdasarkan metode pendekatan yaitu metode Pendekatan Participatory Rural Appraisal (PRA) dan pendekatan sosial. Beberapa program kerja yang dilaksanakan, diantaranya: Senam Sehat, Penyuluhan Cuci Tangan, Pembuatan whiteboard, Pembuatan dan Pemasangan PJU (Penerangan Jalan Umum), Penyuluhan hukum, Mengajar di Lembaga Pendidikan, Membuat Pojok Baca, Pembuatan Blog, Pembuatan Celengan Dari Bahan Bekas, Memberikan Pemahaman Dan Investasi (Mudharabah), Memberikan Penyuluhan Tentang Bagaimana Cara Memulai Bisnis Dan Melatih Berwirausaha, Seminar Pasar Modal Syariah (KSPM), Taman baca, Leadeship training, Pelatihan kerajinan tangan, dan Membuat poster pendidikan. Secara umum, hasil kegiatan telah sesuai dengan rencana yang telah ditetapkan, walaupun ada program yang mengalami hambatan, tapi bisa segera diatasi. Selain itu, respon dari masyarakat Desa Karyasari sangat proaktif dalam setiap kegiatan yang dilaksanakan.
\end{abstract}

Kata Kunci: Karyasari, KKN Tematik Terintegrasi, Peningkatan Masyarakat

\section{PENDAHULUAN}

\section{Analisis Situasi}

Desa Karyasari Kecamatan

Leuwiliang merupakan salah satu tempat yang di pilih dan ditunjuk LPPM untuk menjadi tempat pelaksanaan Kuliah Kerja Nyata yang bertemakan Tematik
Terintegrasi. Dalam satu Desa teridiri dari 2 kelompok yaitu kelompok 17 (Laki-laki) terdiri dari 14 orang dan kelompok 18 (Perempuan) terdiri dari 15 orang yang masing-masing kelompok berasal dari fakultas dan jurusan yang berbeda - beda. 
Berdasarkan hasil survey yang dilakukan, Desa Karyasari mempunyai masyarakat yang heterogen atau beragam. Sehingga dalam penyusunan serta perencanaan suatu program disesuaikan dengan kondisi, situasi dan potensi yang dimiliki oleh lokasi setempat. Setelah melihat hasil survey dan menganalisis daerah maka Tim KKN Posko 17 dan 18 di tempatkan di Desa Karyasari tepatnya di RW 02 dan memilih untuk menyusun program yang mencakup enam bidang yaitu, Kesehatan, Teknik, Hukum, Pendidikan Agama Islam, Ilmu Keguruan serta Ekonomi.

Adapun Program Kerja yang di rencanakan dari bidang kesehatan adalah Senam Sehat, Membantu kegiatan Posyandu, Cek kesehatan Tensi Darah, Penyuluhan Cuci Tangan, Penyuluhan Hipertensi.

Program kerja dari bidang Teknik adalah Pembuatan Rak Buku, Pembuatan plang musholla dan Pemasangan PJU (Penerangan Jalan Umum).

Program kerja dari bidang Hukum adalah Penyuluhan hukum mengenai Surat Kepemilikan Tanah dan Pencatatan Perkawinan.

Program kerja dari bidang Agama Islam adalah Mengajar di PAUD dan TPA, Mengisi Pengajian, Plang Musholla, Membuat Pojok Baca, dan Pembuatan Blog.

Program kerja dari bidang Ekonomi adalah Pembuatan Celengan Dari Bahan Bekas, Memberikan Pemahaman Dan Investasi (Mudharabah) Sejak Dini, Memberikan Penyuluhan Tentang Bagaimana Cara Memulai Bisnis Dan Melatih Berwirausaha Dengan Menggunakan Potensi Sumber Daya Yang Ada Di Masyarakat, dan Seminar Pasar Modal Syariah (KSPM).
Program kerja dari bidang Ilmu Pendidikan adalah Membuat poster bertema pendidikan, Membantu Belajar mengajar, Pelatihan kerajinan tangan, Leadeship training, dan Taman baca.

Dan adapun Program Kerja Unggulan yaitu: Berqurban, Santunan Anak Yatim sekaligus Gebyar Muharram dan Meriahkan Hari Kemerdekaan (17 Agusutus).

\section{Permasalahan Yang Dihadapi}

Melakukan identifikasi masalahmasalah yang dihadapi oleh masyarakat, khusus yang terjadi di Desa Karyasari Kecamatan Leuwiliang, Kabupaten Bogor, memberikan deskripsi atau gambaran yang jelas mengenai faktor-faktor yang mempengaruhi masalah-masalah tersebut. Oleh karena itu sebelum merencanakan program kerja, ditempuh beberapa langkah berupa observasi lapangan, bersosialisasi dengan masyarakat yang meliputi tokoh masyarakat, permerintah setempat, pemuka agama serta melakukan interview dengan masyarakat.

Adapun masalah yang di temukan pada masyarakat Desa Karyasari, sebagai berikut :

a. Bidang Pendidikan dan Agama

- Masih kurangnya tenaga pengajar yang memadai sehingga siswa kurang memperoleh pengetahuan baru dari guru. Tenaga pengajar yang dimaksud yaitu Pendidikan Agama Islam (PAI), dan guru PAUD/TPA.

- Masih kurangnya pengetahuan masyarakat soal pendidikan Islam didalam keluarga.

- Kurang pahamnya pemerintah setempat dan masyarakat dalam mengatasi AKTA dan Perkawinan.

- Minimnya pengetahuan anak-anak dalam bidang B. Inggris. 
- Kurang pahamnya peserta didik untuk bertanggung jawab dalam kepribadiannya maupun dalam berorganisasi.

b. Bidang Ekonomi

- Kurang pahamnya masyarakat tentang investasi mudharabah.

- kurangnya antusias dari masyarakat dalam menghadiri kegiatan yang berbasis ekonomi (keuangan).

- Masih marak sekali adanya Bank Keliling.

c. Bidang Kesehatan

- Kurangnya kesadaran masyarakat dalam menjaga kesehatan. Sebab masih banyak masyarakat yang mengkonsumsi makanan yang kurang baik.

- Sarana dan Prasarana Medis masih kurang memadai.

- Kurangnya pengetahuan Masyarakat mengenai masalah Kesehatan seperti, mencuci tangan.

d. Bidang Teknik

- Kurangnya penerangan pada setiap jalan yang dilalui, khususnya pada RT 02 RW 02 Desa Karyasari.

\section{Solusi yang Ditawarkan}

a. Bidang Pendidikan dan Agama

- Mengisi Pengajian Anak-anak.

- Melaksanakan Pembelajaran di PAUD, SD dan MTS.

- Mengadakan Bimbingan Belajar.

- Mengadakan Penyuluhan Hukum.

- Memotivasi pembelajaran B.Inggris.

b. Bidang Ekonomi

- Membuat celengan dari bahan bekas.
- Memberikan pemahaman dan investasi (Mudharabah) sejak dini.

- Memberikan penyuluhan tentang bagaimana cara memulai bisnis melatih berwirausaha dengan menggunakan potensi sumber daya yang ada dimasyarakat.

c. Bidang Kesehatan

- Mengadakan Senam Sehat.

- Membantu kegiatan posyandu.

- Cek kesehatan tensi darah.

- Penyuluhan cuci tangan.

- Penyuluhan hipertensi.

d. Bidang Teknik

- Pembuatan whiteboard.

- Pembuatan plang musholla.

- Pembuatan rak buku.

- Pembuatan dan Pemasangan PJU (Penerangan Jalan Umum).

Program Tambahan

- Berqurban (Idul Adha).

- Santunan Anak Yatim serta Gebyar Muharram.

- Waqaf Al-Qur'an.

\section{Gambaran Umum Desa Karyasari}

Desa Karyasari berdiri pada tahun 1972 yang merupakan pemekaran dari Desa Karacak dimana pejabat kepala desa Karyasari yang pertama adalah Kokasih yang menjabat mulai dari tahun 19721975, yang kemudian kepala desa kedua dijabat oleh Rais mulai tahun 1975-1984, kepala desa ketiga yang menjabat adalah M. Tawil dari mulai tahun 1984-1992, selanjutnya kepala desa keempat yang menjabat adalah Ujang Suhara. Mulai tahun 1992-1999, selanjutnya dijabat oleh pejabat kepala desa ke lima yaitu M. Rusni tahun 1999-2005, selanjutnya adalah A. Nawawi yang menjabat hingga sekarang. 


\section{Visi dan Misi Desa Karyasari}

Visi Desa Karyasari

Tercapainya pelayanan yang baik di bidang pemerintahan, pendidikan, kesehatan dan pertumbuhan ekonomi pesedaan di dukung dengan penataan sarana, prasarana dan infrastruktur yang dilandasi dengan iman dan taqwa.

Misi Desa Karyasari, anatara lain:

1. Perbaikan pelayanaan kepada masyarakat dibidang pemerintahan.

2. Meningkatkan peran serta kaum lakilaki dan kaum perempuan dalam proses pembangunan dari awal perencana pelaksana dalam pelestarian sesuai tingkat kemampuannya.

3. Meningkatkan pelayanan dan peran serta masyarakat dalam bidang pendidikan dan kesehatan.

4. Menumbuh kembangkan peran serta masyarakat dalam kegiatan ekonomi terutama sector pertanian, perikanan dan usaha skala mikro (para pedagang kecil, pedagang keliling dan lain-lain).

5. Penataan sarana, prasarana dan infrastuktur untuk menunjang peningkatan pendidikan, kesehatan dan perekonomian masyarakat.

6. Meningkatkan kehidupan keagamaan, sosial kemasyarakatan, keamanan dan ketertiban masyarakat.

\section{Sejarah Desa Karyasari}

Desa Karyasari merupakan salah satu desa di kecamatan Leuwiliang Kabupaten Bogor, dengan luas wilayah 605 Ha yang terbagi dalam 6 Dusun, $11 \mathrm{RW}$ dan $31 \mathrm{RT}$. Batas wilayah Desa Karyasari adalah sebagai berikut:

1. Sebelah utara berbatas dengan Desa Karacak.

2. Sebelah selatan berbatas dengan Desa Kecamatan Pamijahan.

3. Sebelah timur berbatas dengan Desa Puraseda.
4. Sebelah utara berbatas dengan Desa Pabangbon.

Gambar 1.1. Peta Lokasi Desa Karyasari

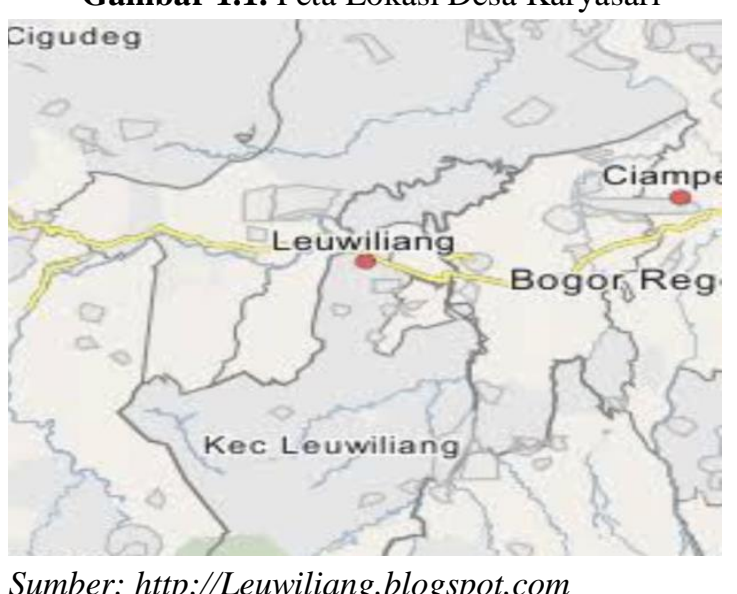

Karyasari adalah desa yang terletak di perbukitan kaki gunung Sanggabuana, sekitar $30 \mathrm{~km}$ kearah barat Bogor yang dapat ditempuh dalam tempo 2,5 jam dari Jakarta menggunakan kendaraan pribadi.

a. Kependudukan

Jumlah penduduk desa Karyasari berdasarkan hasil sensus penduduk tahun 2006 adalah 7966 jiwa. 4105 jiwa laki-laki dan 3861 jiwa perempuan. Dengan jumlah penduduk miskin 1112 kepala keluarga (KK).

Mata pencaharian masyarakat desa karyasari mayoritas bertani, buruh, sebagian berdagang, dan pengusaha kecil serta pegawai negri sipil.

Tingkat pendidikan masyarakat dapat dikatakan masih rendah sebagian besar hanya lulus sekolah dasar (SD), hanya sebagian kecil yang mengenyam pendidikan menengah dan atas.

b. Struktur Kelembagaan Desa

Pemerintahan Desa Karyasari untuk masa bakti 2006-2011 dijabat oleh Awing Nawawi dengan dibantu oleh seorang sekretaris Desa bernama Dedi Sukmedi dan juga dibantu oleh kepala urusan. 
Dalam pengembangan potensi dan pemberdayaan masyarakat kegiatan di desa Karyasari didukung oleh kelembagaan masyarakat, disamping adanya VI Kepala Dusun. Dengan susunan sebagai berikut:

Tabel 1 Susunan Kelembagaan Desa Karyasari Tahun 2006-2011

\begin{tabular}{|l|l|l|}
\hline No & Kelembagaan & $\begin{array}{c}\text { Penanggung } \\
\text { Jawab }\end{array}$ \\
\hline 1. & Ketua LPM & Ma'in \\
\hline 2. & Kepala Dusun I & Markus \\
\hline 3. & Kepala Dusun II & Sahanu \\
\hline 4. & Kepala Dusun III & Ado \\
\hline
\end{tabular}

\begin{tabular}{|l|l|l|}
\hline 5. & Kepala Dusun IV & Amak Faisal \\
\hline 6. & Kepala Dusun V & Madroji \\
\hline 7. & Kepala Dusun VI & Yaya \\
\hline
\end{tabular}

Para Kepala Dusun ini di bantu oleh para ketua RW (Rukun Warga) dan para ketua RT (Rukun Tetangga), di wilayah dusun I terdiri dari 2 RW dan 5 RT, Dusun II terdiri dari 2 RW dna 6 RT. Di wilayah dusun III terdiri dari $2 \mathrm{RW}$ dan $4 \mathrm{RT}$, Dusun IV terdiri dari $1 \mathrm{RW}$ dan $4 \mathrm{RT}$, Dusun V terdiri dari $2 \mathrm{RW}$ dan $8 \mathrm{RT}$, dan Dusun VI terdiri $2 \mathrm{RW}$ dan $4 \mathrm{RT}$. 


\section{METODE PELAKSANAAN}

\section{Tahapan Pelaksanaan}

Tahapan pelaksanaan untuk kegiatan Kuliah Kerja Nyata Tematik Terintegrasi 2019 Kelompok 17 dan 18, Universitas Ibn Khaldun Bogor dibuat dalam bentuk bagan.

\section{Bagan: 1 Tahapan Pelaksanaan Kegiatan KKN}

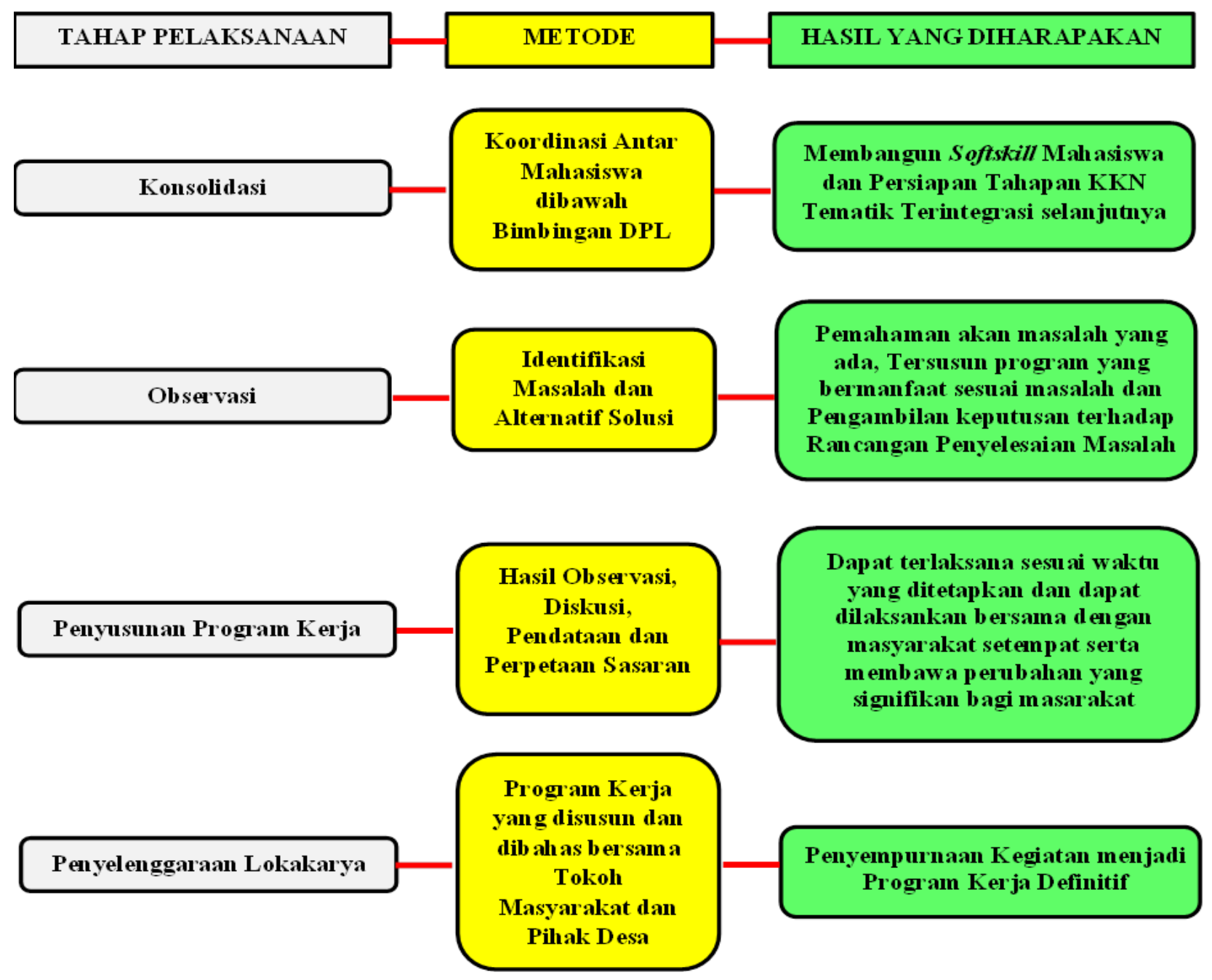

Tabel 2 Jadwal Kegiatan KKN Tematik Terintegrasi Kelompok 17 dan 18

\begin{tabular}{|c|c|c|c|c|c|}
\hline \multirow{2}{*}{ No } & \multirow{2}{*}{ Nama Program } & \multicolumn{4}{|c|}{ Pekan Ke- } \\
\hline & & 1 & 2 & 3 & 4 \\
\hline 1. & Pembukaan dan Pelepasan KKN 2019 & & & & \\
\hline 2. & Penyusunan Rencana kegiatan & & & & \\
\hline 3. & Sosialisasi rencana kegiatan & & & & \\
\hline \multicolumn{6}{|c|}{ BIDANG AGAMA ISLAM } \\
\hline 1. & Mengajar di PAUD \& TPA & & & & \\
\hline 2. & Membuat Plang Mushalla & & & & \\
\hline 3. & Mengisi Pengajian & & & & \\
\hline
\end{tabular}




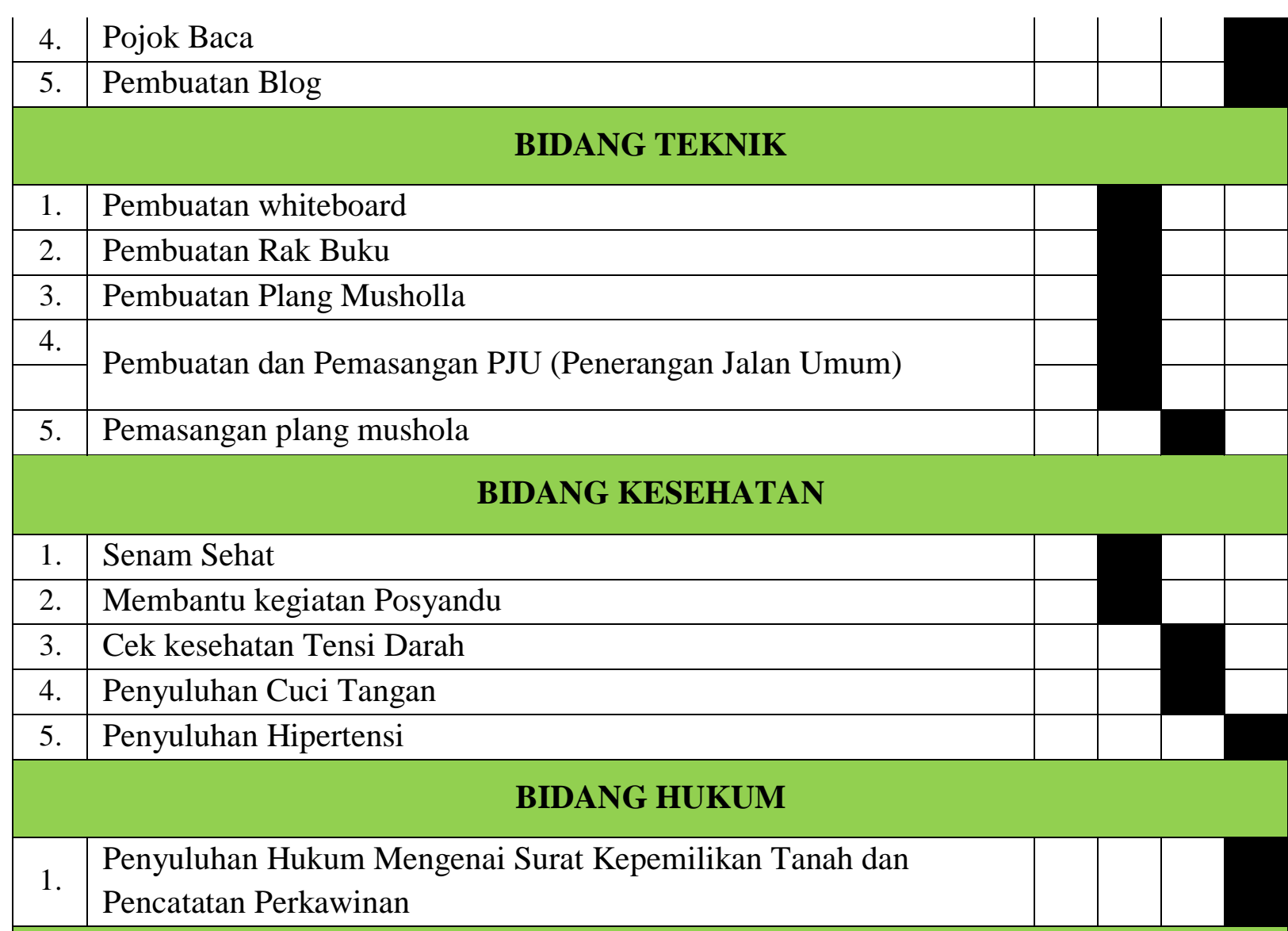

\section{BIDANG EKONOMI}

\begin{tabular}{|c|l|c|c|c|}
\hline 1. & Pembuatan Celengan Dari Bahan Bekas & & \\
\hline 2. & Memberikan Pemahaman Dan Investasi (Mudharabah) Sejak Dini & & & \\
\hline 3. & Penyuluhan Bisnis Melatih Berwirausaha sesuai SDM & & \\
\hline 4. & Seminar Pasar Modal Syariah (KSPM) & & \\
\hline
\end{tabular}

BIDANG PENDIDIKAN

\begin{tabular}{|c|l|c|c|c|}
\hline 1. & Membantu Belajar Mengajar & & & \\
\hline 2. & Membuat Poster Bertema Pendidikan & & & \\
\hline 3. & Pelatihan Kerajinan Tangan & & & \\
\hline 4. & Leadership Training & & & \\
\hline 5. & Taman Baca & & & \\
\hline
\end{tabular}

\section{Metode Pendekatan}

Dalam pelaksanaan Kuliah Kerja Nyata Tematik Terintegrasi Universitas Ibn Khaldun Tahun 2019, pendekatan yang digunakan dalam kegiatan ini, yaitu:

a. Metode Participatory Rural Appraisal (PRA)
Metode ini bertujuan untuk menghasilkan rancangan program yang relevan dengan harapan dan keadaan masyarakat, agar juga diharapkan kemampuan masyarakat dalam menganalisa keadaan mereka sendiri dan diwujudkan dengan melakukan perencanaan dan realisasi dapat 
berkembang, sehingga dapat membuat program dan melaksanakannya. Dalam pendekatan ini mahasiswa hanya sebagai fasilitator sekaligus motivator dan masyarakatlah sebagai pelaksananya.

b. Pendekatan Sosial

Suatu upaya untuk dapat mengintegrasikan diri ke dalam berbagai kegiatan masyarkat agar dapat diterima dan berperan serta dalam berbagai kegiatan masyarakat di tempat KKN. Pendekatan sosial dilakukan dalam seluruh rangkaian pengelolaan kegiatan $\mathrm{KKN}$, baik pada

\section{REALISASI PROGRAM}

\section{Bidang Teknik}

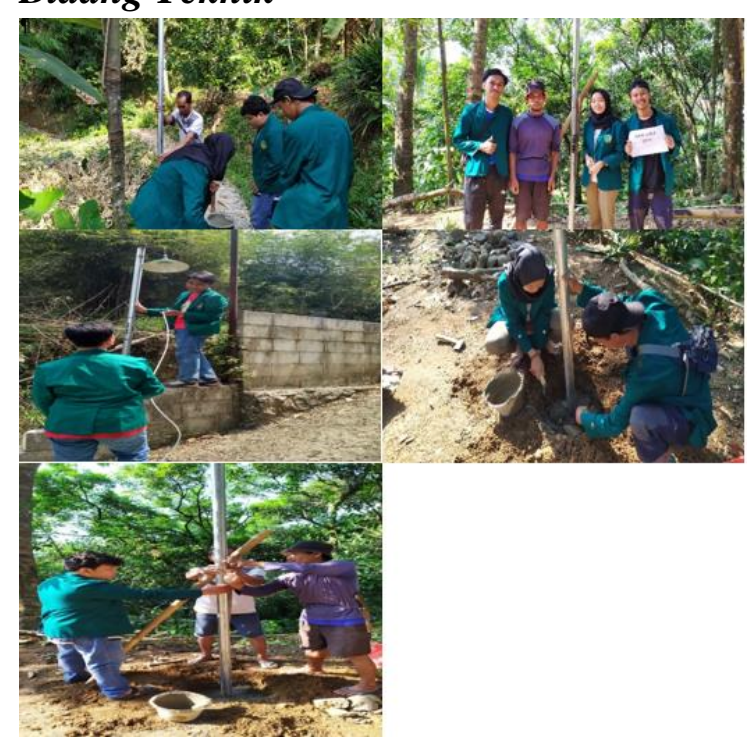

\section{Pembuatan Penerangan jalan}

Pembuatan penerangan jalan ini dipilih karena banyak titik jalan yang sering kita lewati masih minim penerangan , oleh karena itu kita membuat program Penerangan Jalan agar warga desa dapat terbantu pada saat hari mulai gelap. tahap perencanaan, pelaksanaan, maupun pada tahap evaluasi.

\section{Langkah Evaluasi}

Evaluasi yang akan dilakukan terdiri dari:

1. Evaluasi proses, yang terkait dengan perencanaan, pelaksanaan dan monitoring hasil kegiatan. Evaluasi proses akan dilakukan dengan masyarakat atau bisa juga dengan tokoh di desa tersebut.

2. Evaluasi hasil, yang akan dilaksanakan setelah kegiatan dilaksanakan. Evaluasi hasil ditujukan untuk menilai tentang dampak agenda tersebut.

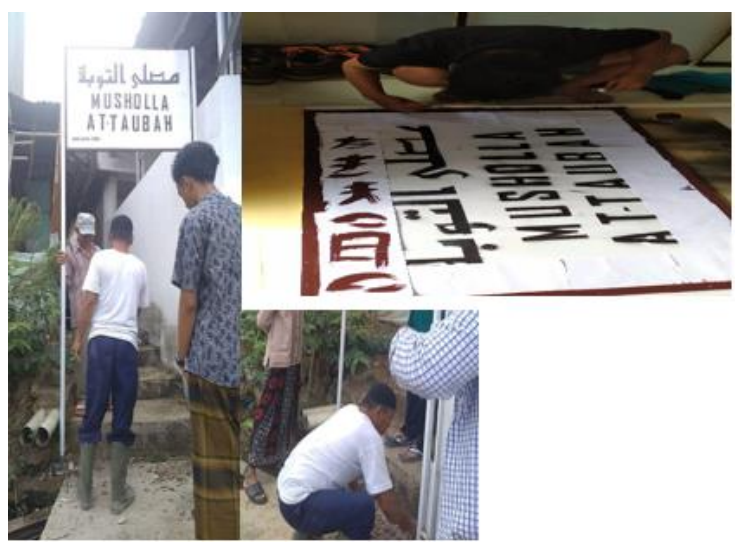

\section{Pembuatan Plang Musholla}

Program kerja pembuatan plang musholla dipilih karena kita melihat plang musholla sebelumnya yang kurang layak untuk ditampilkan, karena hanya terbuat dari papan dan kayu. sehingga timbul keinginan kita unutk membuat plang musholla baru menggunakan bahan yang lebih bagus yaitu menggunakan besi 


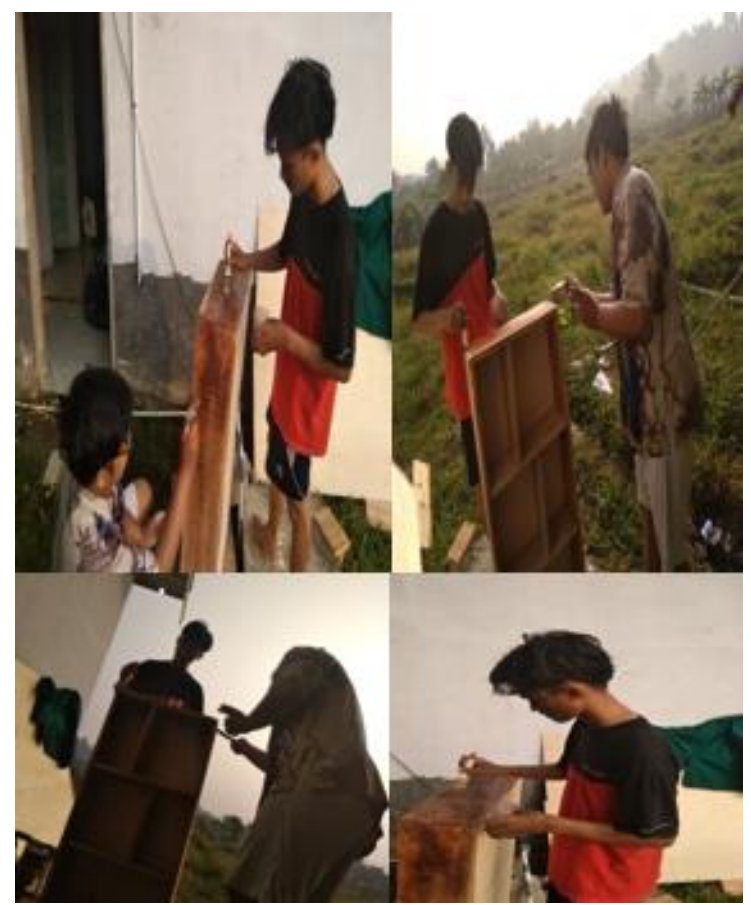

\section{Pembuatan Rak Buku}

Pembuatan rak buku ini merupakan salah satu bagian program kerja yang bekerja sama dengan FKIP dan FAI yaitu pengadaan pojok baca di TPA .

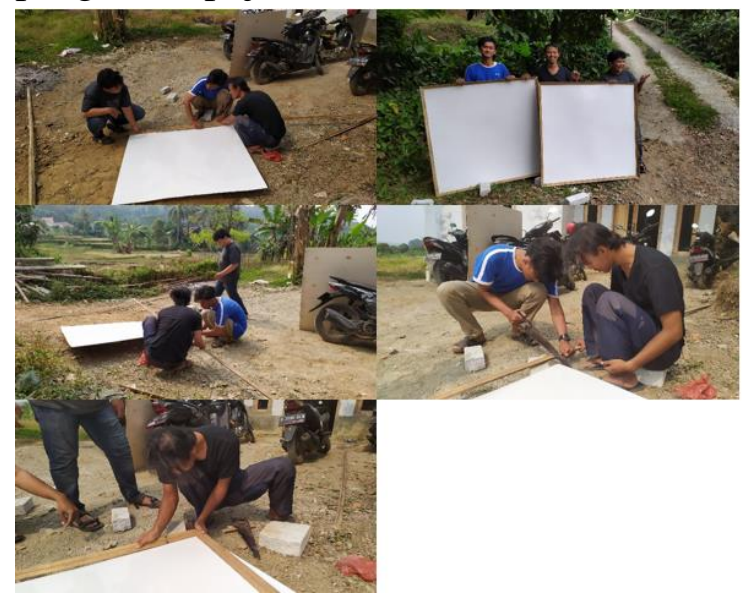

\section{Pembuatan Whiteboard}

Pembuatan Whiteboard untuk pojok baca di TPA, agar anak-anak ada media untuk corat-coret sehingga tidak mengotori tembok.

\section{Bidang Kesehatan}

\section{Senam Sehat}

mengajak warga agar tetap hidup sehat, diadakan nya senam sehat ini didukung baik oleh masyarakat Desa Karyasari sehingga bisa berjalan dengan lancar,Dampak pada rutinitas senam sehat ini bermanfaat bagi masyarakat karena bisa membantu hidupnya agar tetap sehat dan warga antusiasme sehingga gerakangerakannya mudah di hafal dan lancar diikuti oleh warga.

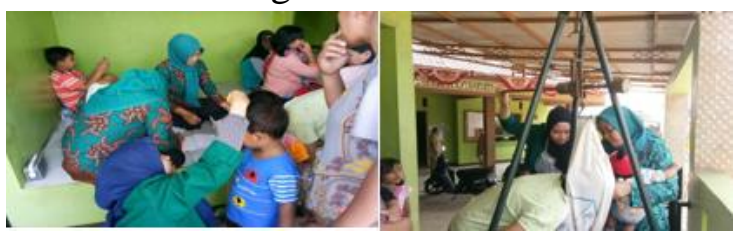

\section{Membantu Kegiatan Posyandu}

Mengajak warga untuk datang ke posyandu mengontrol perkembangan balita, karena ramainya warga yang berdatangan menuju posyandu membawa balitanya untuk melihat perkembangan dan pertumbuhan gizinya, Dampak dari posyandu ini sangat penting bagi perkembangan balita kedepannya namun beberapa ibu-ibu yang punya balita ada yang tidak bisa datang ke posyandu dikarenakan tidak ada waktu karena kerja atau malas untuk ke posyandu

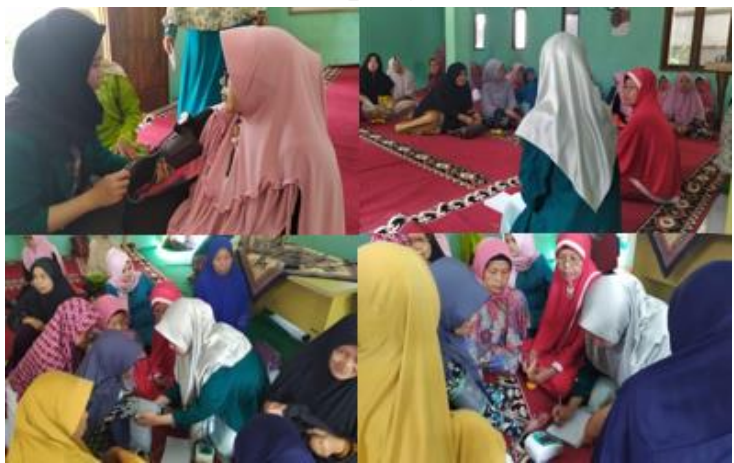

\section{Cek Kesehatan Tensi Darah}

Memberi pencegahan kepada masyarakat agar mengurangi terjadinya resiko tekanan darah tinggi, antusias warga yang ingin di cek kesehatan tekanan darahnya dan banyaknya warga yang mengalami Penyakit Hipertensi. Dampak nya sangat bermanfaat karena bisa tahu bahwa masyarakat Desa Karyasari ini banyak yang mengalami tekanan darah tinggi dan banyak yang tidak rutin meminum obatnya akibatnya tekanan 
darah tinggi tidak mengalami penurunan dan tetap melewati batas normal.

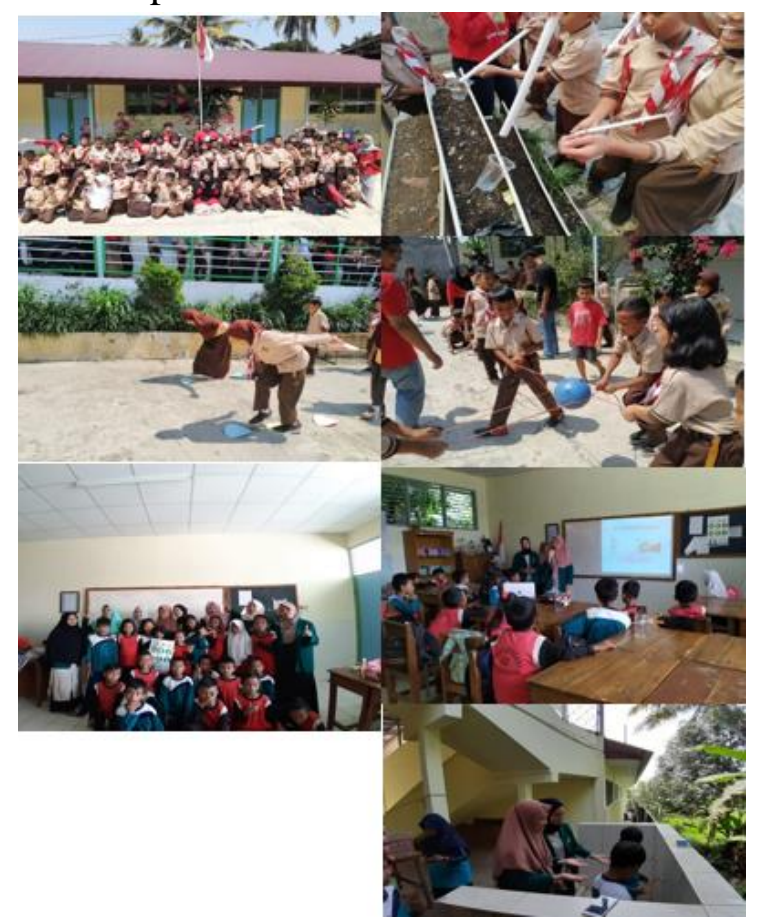

\section{Penyuluhan Cuci Tangan}

untuk memberikan edukasi mengenai cuci tangan yang baik dan benar, karena diadakan penyuluhan cuci tangan baik oleh pihak sekolah dan siswa/i SD Karyasari berjalan dengan lancar serta dapat di pahami dan dimengerti oleh siswa/i yang menjadi peserta dalam penyuluhan cuci tangan. Dampak Penyuluhan cuci tangan ini sangat berguna dan bermanfaat bagi siswa/i kelas IV SD Karyasari, dikarenakan masih awamnya anak yang mengetahui akan pentingnya cuci tangan yang baik dan benar akibatnya masih banyak anak-anak SD yang mengeluh terjadinya diare yang disebabkan tidak membiasakan cuci tangan yang baik dan benar. Oleh karena itu dengan adanya penyuluhan cuci tangan ini anak-anak $\mathrm{Sd}$ dapat teredukasi dan dapat membiasakan diri dalam kehidupan nya masing-masing untuk cuci tangan yang baik dan benar.

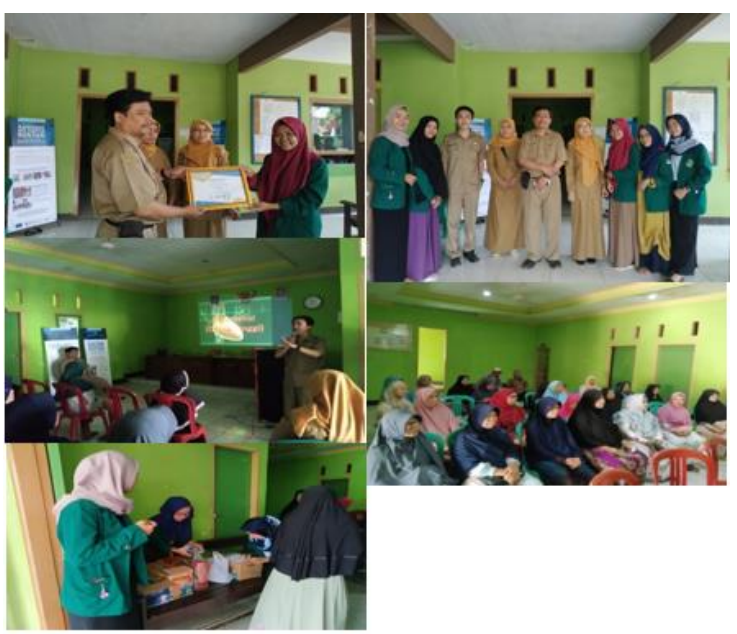

\section{Penyuluhan Hipertensi}

Memberi pencegahan kepada masyarakat agar mengurangi terjadinya resiko tekanan darah tinggi, karena di Desa Karyasari ini banyak yang mengalami hipertensi maka ramainya warga yang berdatangan menuju tempat penyuluhan untuk mengetahui bagaimana pencegahan dan resiko dari hipertensi.Dampak nya sangat bermanfaat bagi masyarakat karena banyaknya yang mengalami hipertensi jadi lebih mengetahui penyakit-penyakit apa saja yang akan di alami ketika hipertensi ini tidak rutin di obati atau tidak rutin menghindari makanan-makanan atau faktor yang bisa mengurangi terjadinya hipertensi.

\section{Bidang Agama Islam}

Pemahaman Agama di desa ini bisa dikatakan masih kurang namun sudah mulai meningkat dari pengajian-pengajian yang rutin dilaksanakan, dan masih kekurangan tenaga pengajar maupun pendidik.

Ketersediaan fasilitas dan sarana prasarana cukup memadai, hanya saja untuk jaringan internet masih kurang karena hanya tersedia disudut-sudut tertentu saja. Adapun kondisi jalanan umum yang banyak berlubang sehingga butuh kehati-hatian bagi para pengendara kendaraan. 
Tantangan bagi kami ialah mengubah pandangan masyarakat tentang pentingnya pendidikan terlebih pendidikan serta pemahaman agama. Karena mengubah pandangan (mindset) masyarakat tidaklah mudah, apalagi jika dibenturkan dengan kebutuhan (realitas).

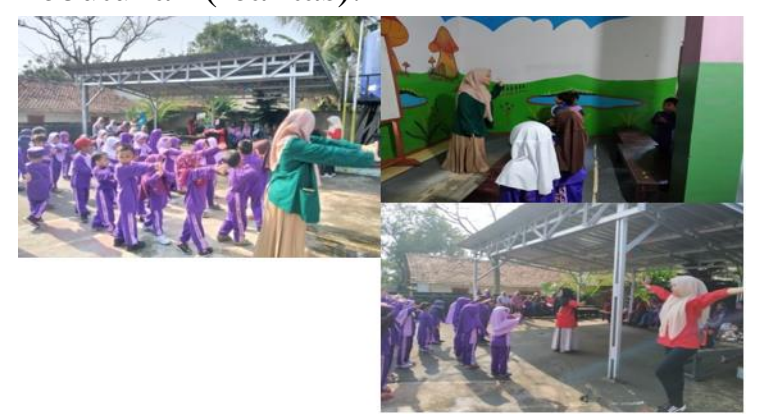

\section{Mengajar di PAUD \& TPA}

Mengajar di PAUD dan TPA Bahrul Hidayah selama kurang lebih dua minggu. Sasarannya anak-anak usia sekitar 3-13 tahun. Mengajar di PAUD mulai dari pukul 08.00-10.00 WIB, sementara mengajar di TPA mulai pukul 13.00-14.30 WIB. Adapun materi maupun jadwal mengikuti yang sudah ada sebelumnya. Beberapa metode lain yang coba kami praktekan yaitu materi dijadikan sebuah lagu yang memang mudah dihafal bagi anak-anak. Alhamdulillah anak-anak sangat antusias. Beberapa tipe anak-anak di PAUD dan TPA ini cukup aktif banyak bergerak meski begitu mereka tergolong cepat untuk menghafal, ditemukan juga beberapa tipe anak yang memang pendiam dan bahkan masih diantar oleh orang tuanya sampai masuk kelas serta ditunggu hingga jam belajar selesai.

Di desa Karyasari sendiri memang masih kekurangan tenaga pengajar khususnya dibidang agama. Hal tersebut salah satunya disebabkan oleh masih kurangnya edukasi masyarakat tentang sekolah hingga perguruan tinggi maupun pondok pesantren selain itu factor lainnya yaitu tingkat ekonomi yang rendah membuat para orang tua tidak ingin menyekolahkan anaknya hingga jenjang atas. Alhasil tenaga pengajar masih sedikit di desa karyasari ini.

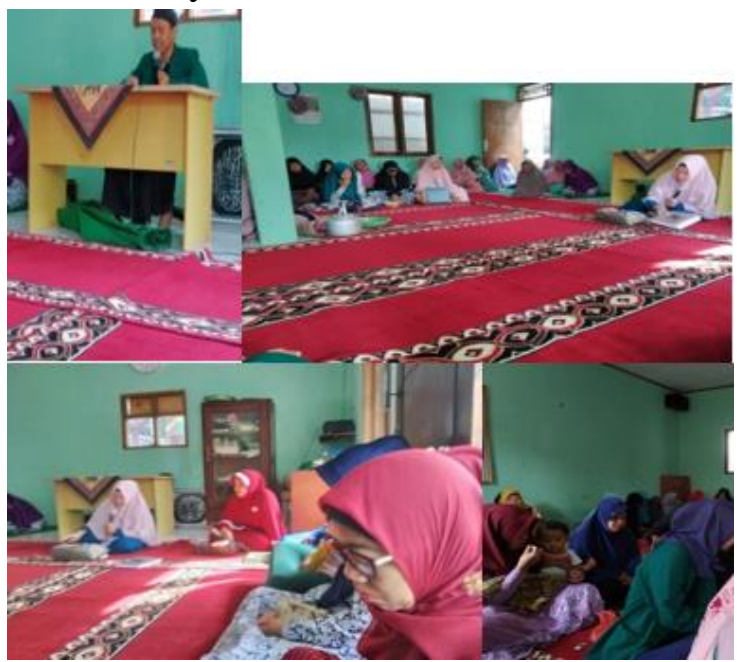

\section{Mengisi Pengajian}

Mengisi pengajian merupakan salah satu kesempatan bagi kami untuk saling sharing, saling belajar, dan juga melaksanakan kewajiban berdakwah walau sedikit-sedikit. Sasaran dari pengajian ini ialah ibu-ibu di desa Karyasari, Alhamdulillah ibu-ibu yang sudah dapat dikatakan sebagai lansia juga masih terlihat menghadiri pengajian ini.

Pengajian ibu-ibu Alhamdulillah memang sudah rutin diadakan setiap seminggu dua kali yaitu hari Selasa dan Jum'at. Adapun materi yang disampaikan ialah 4 perkara yang dapat menyempurnakan islamnya seseorang yaitu, jujur, syukur, memiliki rasa malu, dan perangai yang baik.

Dalam pengajian rutin ini tidak hanya penyampaian materi-materi saja namun juga disertai membaca Al-qur'an bersama-sama. 


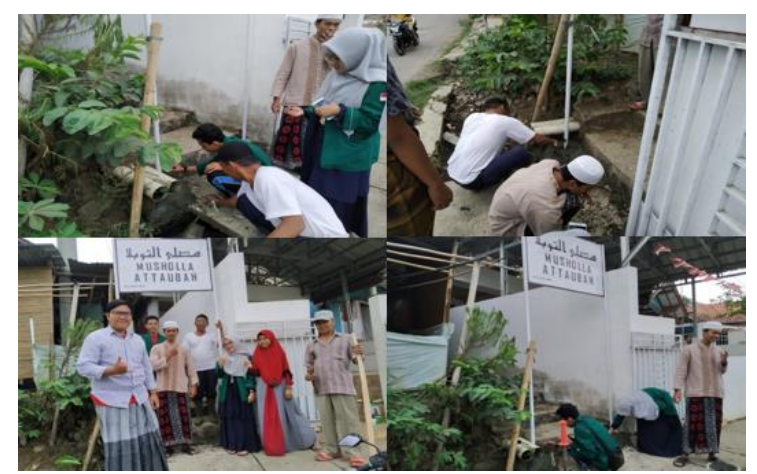

2. Penulisan Lafadz di Plang Musholla

Plang Musholla sendiri memang awalnya merupakan harapan dari warga khususnya rw 02 karena memang plang sebelumnya sudah layak diganti. Dalam proses pembuatan plang ini, kami bekerjasama dengan fakultas teknik.

Sasarannya ialah warga sekitar Musholla At-Taubah, disertai dengan harapan musholla ini bisa lebih ramai lagi, digunakan untuk beribadah dan juga bisa lebih terlihat oleh lalu lalang orang yang melewati depan musholla untuk melaksanakan sholat.

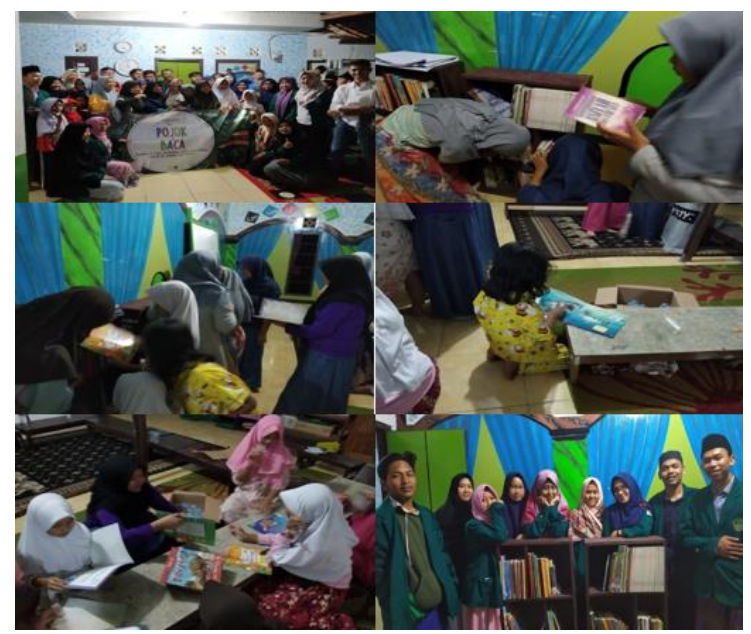

\section{Menyelenggarakan Pojok Baca}

Pojok baca diresmikan pada Senin, 26 Agustus 2019, setelah sebelumnya anak-anak sering mampir ke posko perempuan untuk belajar dan membaca buku bersama. Sasaran dari pojok baca ini bersifat umum untuk semua kalangan yang ada. Pojok Baca desa Karyasari ini kami tempatkan di yayasan bahrul hidayah dengan pertimbangan akan ada yang mengurusnya dan memang tempat ini rutin dihadiri anak-anak, remaja dan juga ibuibu serta bapak-bapak. Selain itu karena tempat tersebut juga dekat dengan masjid.

Proker ini juga kami bekerja sama dengan fakultas teknik untuk pembuatan rak bukunya.

Awalnya niat kami ialah ingin membentuk sebuah pojok baca sekaligus menjadi tempat bimbingan belajar (bimbel) dengan mengkader pemuda-pemudi di desa karyasari. Namun karena keterbatasan tempat dan sulitnya mengajak pemuda untuk ikut serta mengajar adik-adiknya maka kami putuskan hanya membentuk pojok bacanya saja tanpa bimbel, sementara bimbel hanya dilaksanakan ketika kami masih berada di desa karyasari.

Tujuan kami mengadakan pojok baca ini bermaksud untuk meningkatkan minat baca masyarakat desa karyasari, terutama pada anak-anak yang mulai lebih suka dan asyik bermain gadget daripada membaca buku. Padahal banyak hal yang bisa didapatkan dari membaca buku. Kedepannya pojok baca ini bebas dikunjungi masyarakat desa karyasari kapanpun mereka mau.

Alhamdulillah sejauh itu anak-anak sangat antusias membaca buku-buku yang ada. Buku-buku nya sendiri kami membuka donasi, baik perseorangan maupun kelompok. Buku yang kami terima kurang lebih ada 100 buku. 


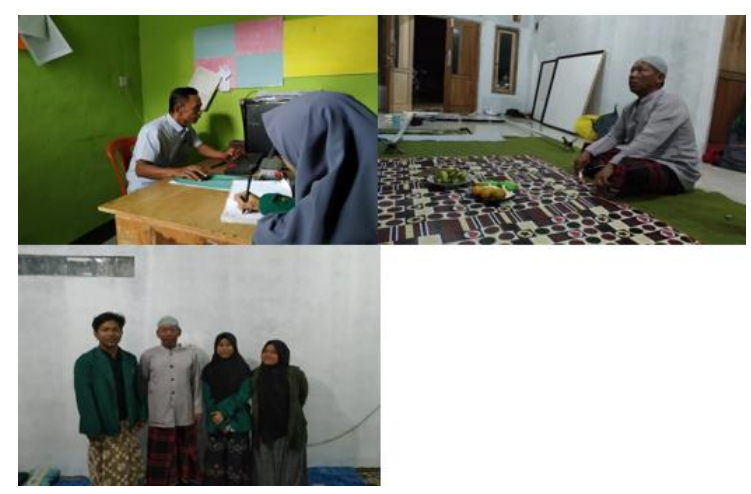

4. Membuat Blog Desa

Proker ini berawal dari semenjak kami tau bahwa kami akan kkn di desa karyasari, bermaksud mencari informasi dari desa karyasari di google ternyata belum ada informasi-informasi tentang desa karyasari. Oleh karena itu muncul lah ide untuk membuat blog desa.

Tujuan dari blog desa ini ialah agar karyasari bisa dikenal serta memiliki wadah untuk mempromosikan desa karyasari, seperti potensi-potensi yang ada di desa karyasari. Hambatan dari blog desa ini ialah sinyal internet yang kurang memadai selain itu minat ingin belajar dan mengelola blog ini masih sangat minim.

Sasaran dalam pembuatan blog ini ialah para pemuda, namun sayangnya belum ada yang mau mengelolanya. Kami menggunakan blogger sebagai medianya itupun kami pilih yang tidak berbayar dengan tujuan agar tidak membebani penggunanya kelak.

Wawancara kami lakukan mulai dari ketua RW hingga pihak desa nya langsung, dan juga ada beberapa opini masyarakat yang kami tampung.

\section{Bidang Ekonomi}

\section{Pembuatan Celengan Dari Bahan Bekas}

Program Kerja ini kami canangkan dari hasil observasi kami mengenai sampah yang ada dilingkungan dan cukup banyak anak-anak yang belum mempunyai tabungan/celengan serta kegembiraan mereka dalam berkreasi. Dan program ini didukung dengan memanfaatkan sampah plastik atau kayu seperti botol plastik dan lainnya yang kemudian di gunting, diukir, dicat hingga dibentuk menjadi yang kita inginkan seperti karakter kartun yang nantinya akan lebih menarik simpatik sasaran kami.

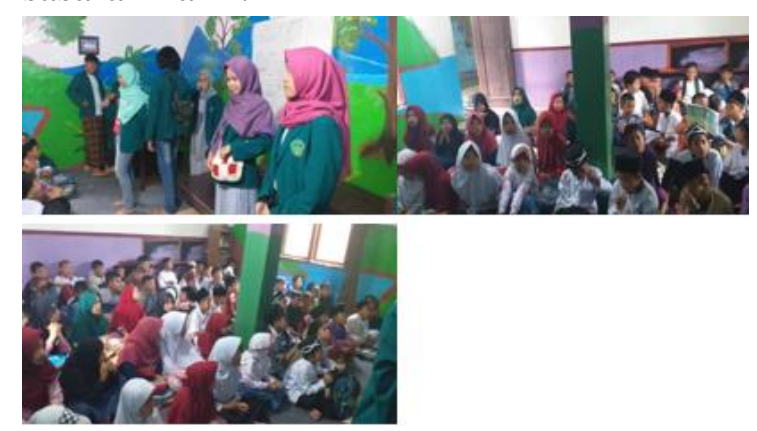

2. Memberikan Pemahaman Dan Investasi (Mudharabah) Sejak Dini

Program kerja ini disusun dan dihidangkan dengan teori tentang Investasi dengan sistem Bagi Hasil (Mudharabah) yang kemudian kami berikan kepada sasaran kami untuk dipahami dan dilaksanakan dengan dinaungi oleh kami.

Ketika selesai diberi pemahaman tentang pentingnya berinvestasi, lalu kami mengsimulasikan dalam lingkup kecil yaitu diruang lingkup anak-anak. Kami mengumpulkan Uang sebesar 2000 rupiah dari masing-masing anak yang kemudian nanti akan kami kelola untuk dijadikan modal dalam berwirausaha dan keuntungannya kami bagi dua dengan pemodal yaitu anak-anak.

Berdasarkan sasaran, terkumpullah uang sebesar Rp 60.000 dari 30 murid TPA Bahrul Falah untuk kami putar kembali menjadi modal usaha yang kami rencanakan sebelumnya. Usaha yang kami lakukan adalah pembuatan “ Es Kul - kul dan Pisang Nugget" dengan sasaran pasar di Warung dan Warga sekitar posko KKN. 
Dengan begitu, dari perputaran usaha kami mnghasilkan laba rata-rata sebesar $80 \%$ dari modal yang ditanamkan oleh murid murid TPA Bahrul Falah. Sehingga setiap murid mendapatkan keuntungan dalam sekali perputaran modal sebesar Rp. 1.600. program ini kami lakukan satu bulan penuh (30 hari) sejalan dengan perputaran modal atau usaha yang kami lakukan sebanyak 30 hari.

Berdasarkan modal 60.000 yang kami belanjakan untuk bahan-bahan berjualan. (terlampir) menghasilkan untung Rp. 48000 yang apabila kami jumlahkan dengan modal menjadi Rp. 108.000 dalam 1 hari yang jika dikalikan 30 hari menjadi Rp. 3.240.000 atau setiap anak mendapatkan Rp. 48.000 laba investasi dan 60.000 modal yang ditanamkan setiap hari. Sehingga total yang didapatkan sebesar 108.000 .

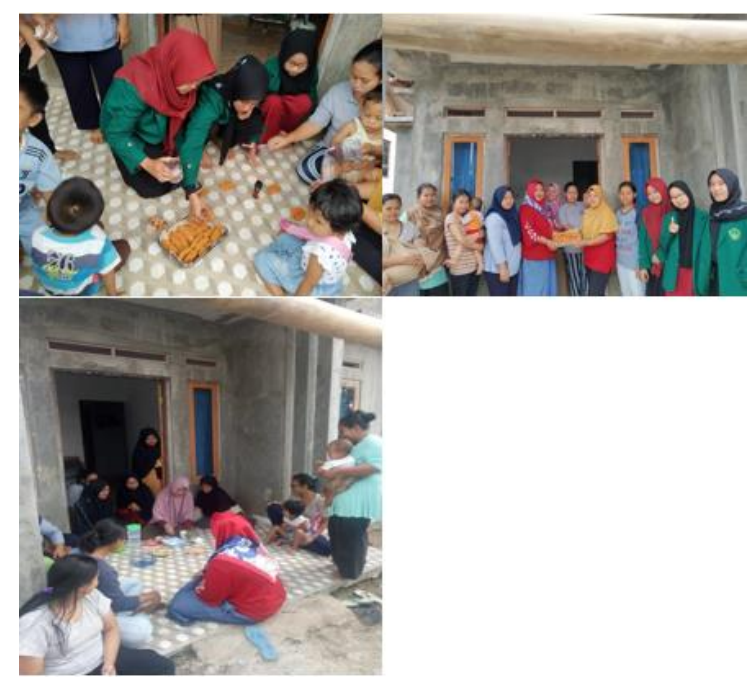

3. Memberikan Penyuluhan Tentang Bagaimana Cara Memulai Bisnis Dan Melatih Berwirausaha Dengan Menggunakan Potensi Sumber Daya Yang Ada Di Masyarakat

Program Kerja ini diadakan untuk memberikan pengertian bagaimana cara memulai berbisnis dengan adanya dukungan teknologi yang ada dan hal ini disampaikan oleh mahasiswa fakultas ekonomi dan ekonomi syariah dari hasil studi yang dipelajari, sekaligus melatih berwirausaha dengan menggunakan potensi sumber daya alam yang ada dimasyarakat, dalam hal ini kami pilih buah pisang, karena hasil survey kami yang dibantu dengan narasumber warga sekitar, bahwa banyak dari warga sini yang berkebun menanam pisang yang setiap panen nya di supply ke pasar sekitar.

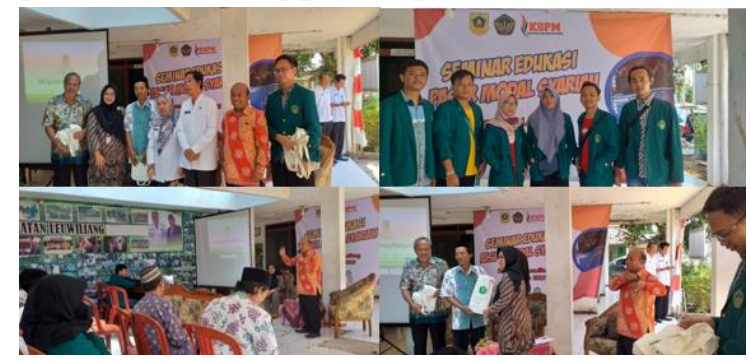

4. Seminar Pasar Modal Syariah (KSPM)

Seminar Pasar Modal Syariah yaitu kegiatan seminar dimana kami menghadirkan narasumber langsung berasal dari Bursa Efek Indonesia yang sekaligus membantu kami untuk menyampaikan wawasan tentang investasi syariah. Program Kerja (gabungan) ini diselenggarakan oleh seluruh mahasiswa Fakultas Ekonomi dan prodi Ekonomi Syariah dari Faskultas Agama Islam UIKA yang tengah KKN di Kecamatan Lewiliang.

\section{Bidang Hukum}

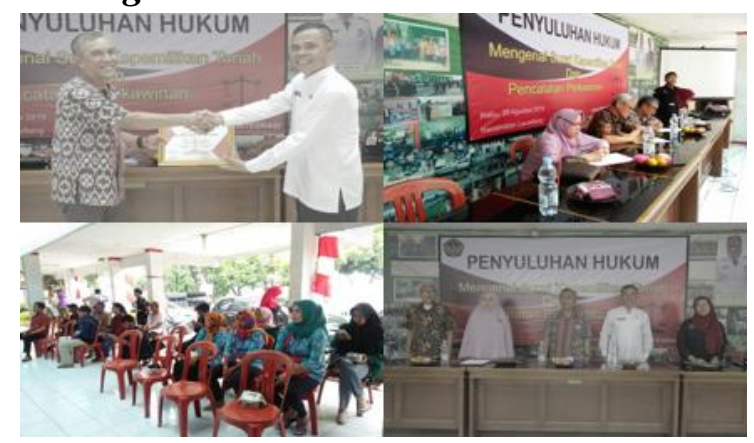

Program kerja yang dilaksanakan bidang hukum adalah Penyuluhan hukum mengenai Surat Kepemilikan Tanah dan Pencatatan Perkawinan 


\section{Bidang Pendidikan}

Pada bidang pendidikan kami melihat adanya kekurangan prasarana terkait Pendidikan di Desa Karyasari, maka dari kami berinisitif untuk membantu dalam bidang Pendidikan di desa tersebut.
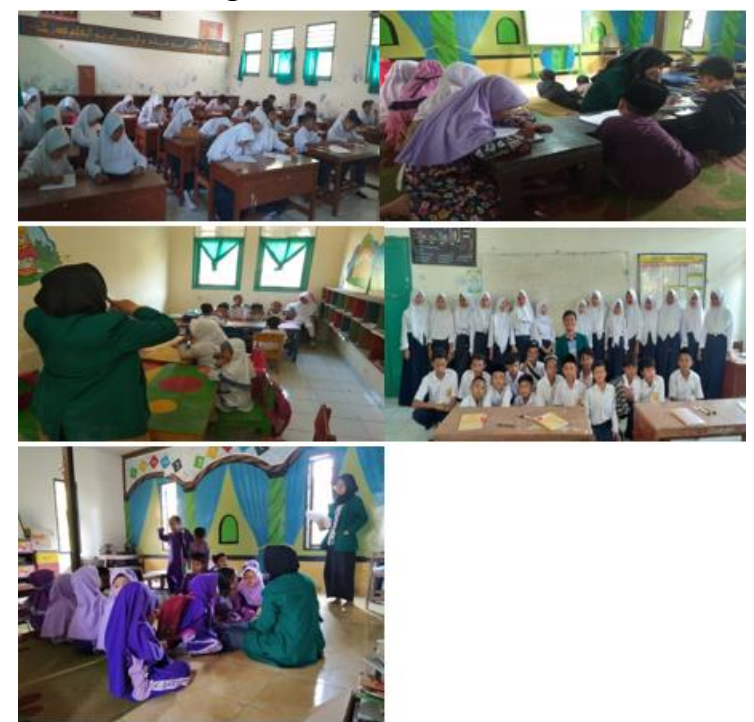

\section{Membantu Mengajar}

Kegiatan belajar mengajar di Mts Hidayatul Falah dan RA Bahrul Hidayah. Membantu kegiatan belajar mengajar di Mts Hidayatul Falah dan membantu meningkatkan motivasi siswa dengan menggunakan metode pembelajaran yang sesuai dengan kebutuhan siswa agar semangat belajar dan belajaran menjadi efektif.Program terlaksana, karena program belajar mengajar ini sangat di dukung oleh pihak sekolah sehingga program kerja ini berjalan dengan lancar.Selain dari pada materi yang sudah ditetapkan pihak sekolah kami diberi waktu diakhir mata pelajaran untuk membuat pendekatan emosional kepada murid-murid yang mana itu adalah pesan-pesan moral yang harus dilakuakan dilingkungan sekolah maupun desa.

\section{Membuat poster bertema pendidikan}

Memberi motivasi kepada siswa/i agar terus semangat dalam belajar dan mengajak siswa/i untuk melakukan hal-hal yang sudah di tuliskan dalam poster. kegiatan ini disetujui oleh pihak guru karena masih banyak siswai SDN Karyasari 2 yang belum banyak mengetahui slogan/poster pendidikan sehingga program kerja ini berjalan dengan lancar. Penyebaran poster pendidikan tentu berisikan pesan moral dan penyemangat bagi siswa/i SDN Karyasari 2.

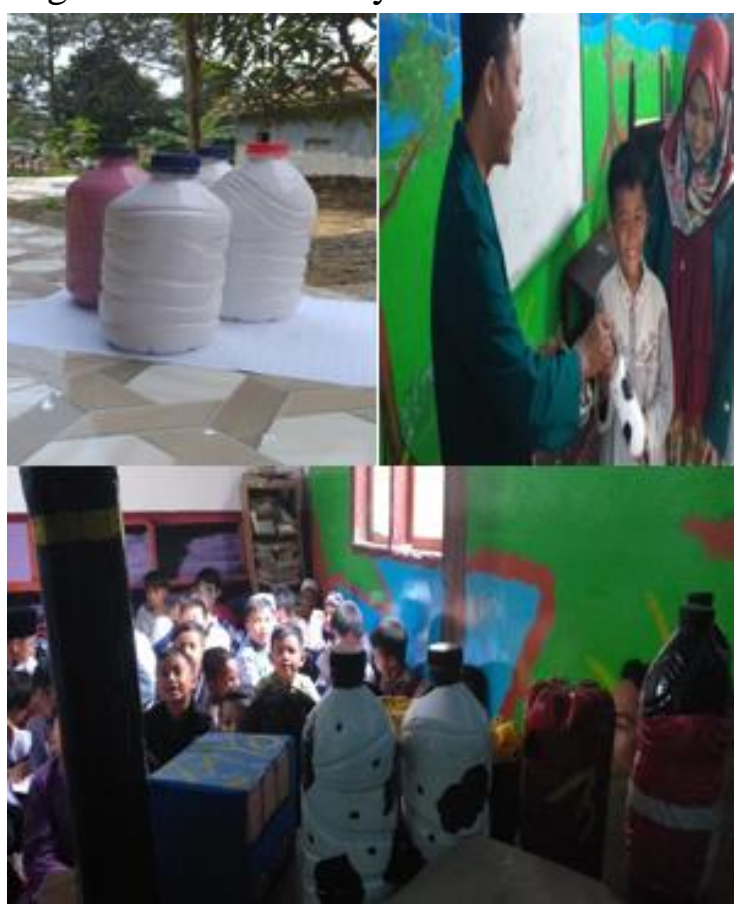

\section{Pelatihan kerajinan tangan}

kegiatan keterampilan tangan yang dibuat secara manual dengan tangan sebagai upaya mengubah suatu benda agar lebih memiliki nilai guna dan nilai jual lebih tinggi.Kegiatan kerajinan tangan ini sangat di terima dengan baik oleh pemudipemudi di desa Karyasari karena bisa membuka peluang bisnis hanya dengan bermodalkan tali.Pemuda sekitar menjadi lebih tertarik untuk mempelajari kerajinan tangan lainnya dan bisa lebih mandiri setelah itu.

\section{Leadership training}

kegiatatan latihan dasar kepemimpinan dengan cara bermain.untuk belajar menanamkan jiwa kepemimpinan siswai/i, belajar berkerja dengan 
kelompok. Kami bisa menyampaikan dengan baik kegiatan ini baik dari materi dan juga non-materi seperti game-game yang kami terapkan, materi tersebut berisikan bagaimana anak mau berkembang dan mempunyai cita-cita sejak dini.Pada dasarnya anak-anak memang lebih tertarik pada, tetapi dari pada itu kita memberikan kebebasan berfikir untuk menyimpulkan apa pesan dari game tersebut, terkait kekompakan, kejujuran, dan kepemimpinan.

\section{KESIMPULAN}

Kuliah Kerja Nyata Tematik Terintegrasi sangatlah bermanfaat bagi mahasiswa, sebagai sarana untuk lebih mengenal kehidupan bermasyarakat dan sebagai ajang untuk mengaplikasikan ilmu yang telah di dapat selama menempuh pendidikan di kampus. Sehingga ilmu yang kami dapatkan selama ini dapat berguna dan bermanfaat bagi masyarakat. Berdasarkan evaluasi dari kegiatan $\mathrm{KKN}$ kelompok 17 dan 18 yang dilakukan di Desa Karyasari Kecamatan Leuwiliang Kabupaten Bogor berjalan lancar dan antusias dan sambutan masyarakat pun cukup baik dan masyarakat sangat terbuka dengan kami sehingga program kerja yang kami telah rencanakan dapat terealisasikan dengan presentase sekitar $95 \%$.

Mengingat adanya permasalahan yang ada di lingkungan masyarakat RW 01 Desa Cibeber I, Kec. Leuwiliang Kab. Bogor diantaranya :

a. Bidang Agama Islam

Permasalahan:

1. Kurangnya tenaga pengajar yang memadai sehingga kadang siswa tidak memperoleh pengetahuan baru dari guru.

2. Masih minimnya pengetahuan tentang Agama.

\section{Taman baca (bekerja sama dengan FAI)}

Menambah minat baca anak-anak dan warga sekitar.Perlu diketahui kami bekerjam saama dengan FAI untuk mengakomodir buku-buku yang bermanfaat, pun rak juga dibuat oleh teman-teman dari fakultas Teknik.Menambah minat baca warga sekitar dan anak-anak tentu untuk memiminimalisir penggunaan gaget.

3. Kesadaran akan pentingnya pendidikan masih sangat rendah.

4. Masih kurangnya pengetahuan masyarakat soal pendidikan Islam didalam keluarga.

Penanggulangan :

1. Mengadakan Pengajian Anak-anak.

2. Melaksanakan Pembelajaran di PAUD/TPA/SD/MTS.

3. Pojok Baca.

4. Mengadakan Bimbingan Belajar.

b. Bidang Ekonomi

Permasalahan:

1. Kurangnya pemanfaatan barang bekas.

2. Minimnya memahami tentang pentingnya investasi.

3. Kurang pahamnya warga dalam berbisnis.

Penanggulangan:

1. Pembuatan Celengan Dari Bahan Bekas.

2. Memberikan Pemahaman Dan Investasi (Mudharabah) Sejak Dini.

3. Memberikan Penyuluhan Tentang Bagaimana Cara Memulai Bisnis Dan Melatih Berwirausaha Dengan Menggunakan Potensi Sumber Daya Yang Ada Di Masyarakat.

4. Seminar Pasar Modal Syariah (KSPM). 
c. Bidang Kesehatan

Permasalahan:

1. Kurangnya kesadaran masyarakat dalam menjaga lingkungan sekitar. Sebab masih banyak kesehatan masyarakat yang tidak baik, sebab pola makan yang tidak teratur.

2. Sarana dan Prasarana Medis masih kurang memadai.

3. Kurangnya pengetahuan masyarakat mengenai masalah Kesehatan .

4. Kurang pahamnya masyarakat dalam mencuci tangan dengan benar.

Penaggulangan:

1. Mengadakan Senam Sehat.

2. Membantu kegiatan Posyandu.

3. Cek kesehatan Tensi Darah.

4. Penyuluhan Cuci Tangan.

5. Penyuluhan Hipertensi.

d. Bidang Teknik

Permasalahan:

1. Kurangnya penerangan jalan.

Penanggulangan:

1. Pembuatan plang mushola.

2. Pembuatan whiteboard.

3. Pembuatan Rak Buku.

\section{REKOMENDASI}

Dari hasil pelaksanaan KKN kelompok 17 dan 18 di Desa Karyasari Kecamatan Leuwiliang Kabupaten Bogor ada beberapa rekomendasi dan saran yang mungkin dapat ditindak lanjuti kedepannya agar lebih baik lagi;

1. Dukungan dan perhatian dari aparat Kelurahan/Desa sudah baik, namun perlu di tinggkatkan lagi.

2. Sosialisasi mengenai KKN Tematik Terintegrasi tidak hanya kepada aparat
4. Pembuatan dan Pemasangan PJU (Penerangan Jalan Umum).

e. Bidang Hukum

Permasalahan:

1. Kurangnya pemahaman masyarakat terhadap hukum mengenai Surat Kepemilikan Tanah dan Pencatatan Perkawinan

Penanggulangan:

1. Penyuluhan hukum mengenai Surat Kepemilikan Tanah dan Pencatatan Perkawinan.

f. Bidang Pendidikan

Permasalahan:

1. Kurangnya tenaga pendidik.

2. Kurang kreatifnya masyarakat sekitar.

3. Kurang pahamnya peserta didik mengenai tanggung jawab dalam berorganisasi.

Penanggulangan:

1. Membantu Belajar mengajar.

2. Membuat poster bertema pendidikan.

3. Pelatihan kerajinan tangan.

4. Leadeship training.

5. Taman baca (bekerjasama dengan Fakultas Agama Islam).

pemerintah, namun sebaiknya oleh LPPM kepada Masyarakat yang berinteraksi langsung dengan Mahasiswa peserta KKN Tematik Terintegrasi dapat dilaksanakan sebelum penerjunan.

3. Perlu adanya dukungan dari LPPM untuk pemantauan yang berkelanjutan mengenai beberapa program yang perlu ada tindakan berkelanjutan. 


\section{DAFTAR PUSTAKA}

Desa Cibeber I. 2014. Peta Desa Cibeber I Kecamatan Leuwiliang. [Online] diakses pada Selasa, 02 September 2019.

desacibebersatu.blogspot.com/2014/0

3/peta-desa-cibeber-i-kecamatan-

leuwiliang.html?m=1

Goeritno, A. Nuraeni, F. dan Haqieqi, J.J. (2018). Pemberdayaan Masyarakat Dalam Rangka Keterwujudan Interaksi Sosial dan Kesejahteraan di Desa Cibeber I. Jurnal Pengabdian Pada Masyarakat, Vol. 2 Nomor 4, 332-341.
Ikhsan, MZ., Prasetya, EP. (2020). Sosialisasi Pendidikan Stop Aksi Bullying. PKM-P, 4 (1).

Prasetya, E. (2018). Pemberdayaan Masyarakat Tentang Kesehatan, Pendidikan dan Kreatifitas. Abdi Dosen: Jurnal Pengabdian Pada Masyarakat 2 (1), 19-25.

Sudrajat, A. 2008. Pendekatan Sosial. [Online] diakses pada Jum'at, 30 Agustus 2019. akhmadsudrajat.wordpress.com/2008 /02/14/pendekatan-sosial-dalamkegiatan-kkn/amp/ 